\section{Good Life Project: Description of the Impact of Weight Loss Intervention at a Private Health Service in Manaus}

\author{
Ananda Castro Chaves ${ }^{1}$, Rafaela Melo Campos Borges ${ }^{1}$, Ana \\ Cecília Lima', Ábner Souza Paz², Lia Mizobe Ono ${ }^{3}$, William \\ Hiromi Fuzita ${ }^{4}$ and Caroline Souza dos Anjos ${ }^{4 *}$
}

${ }^{1}$ Clinical Physicians, Manaus, Av. Gov. Danilo de Matos Areosa, Amazonas, Brazil

${ }^{2}$ Oncologic Nutritionist, Sensumed Oncologia, Manaus, Amazonas, Brazil

${ }^{3}$ Dental Surgeon, Sensumed Oncologia, Manaus, Amazonas, Brazil

${ }^{4}$ Clinical Oncologist, Sensumed Oncologia, Manaus, Amazonas, Brazil

\begin{abstract}
\section{Introduction}

Cardiovascular diseases, followed by neoplastic diseases and complications of diabetes, are among the major causes of death worldwide. All of them are directly related to the life style of most of the population. Today it is know that weight loss contributes to the
\end{abstract} reduction of the incidence of these diseases.

\section{Objective}

To describe the impact of weight loss intervention for the promotion of health at a private oncology clinic in Manaus-AM.

\section{Patients and methods}

This was a longitudinal, prospective, observational and descriptive study conducted on 41 employees of Sensumed Oncologia.

\section{Results}

36 patients were weighed in the first and $6^{\text {th }}$ month of the study, with a 1.08 to $19.34 \%$, weight loss for a total amount of $43.74 \mathrm{~kg}$. A total of $72.22 \%$ of the subjects practice regular physical activity, with $30 \%$ of them starting to do during the project. The greatest impact on laboratory tests was a reduction of the lipid profile, although there

${ }^{*}$ Corresponding author: Caroline Souza dos Anjos, Clinical oncologist, Sensumed Oncologia, Manaus, Amazonas, Tel: +55 09221295675; E-mail: carolinesanjos@gmail.com

Citation: Chaves AC, Borges RMC, Lima AC, Paz ÁS, Ono LM, et al. (2019) Good Life Project: Description of the Impact of Weight Loss Intervention at a Private Health Service in Manaus. J Food Sci Nut 5: 046

Received: July 27, 2019; Accepted: September 03, 2019; Published: September 10, 2019

Copyright: (C) 2019 Chaves AC, et al. This is an open-access article distributed under the terms of the Creative Commons Attribution License, which permits unrestricted use, distribution, and reproduction in any medium, provided the original author and source are credited. was also a discrete reduction of fasting glycemia in both sexes without pharmacological measures.Bioimpedance revealed a modest reduction of fat mass.

\section{Conclusion}

A more intensive intervention regarding health promoting activities is necessary, mainly where large part of the population spends most of the day in the workplace. Thus, it is possible to prevent obesity, a serious public health problem, thus reducing the morbidity and mortality of the population and the incidence of this important risk factor for the onset of chronic diseases.

Keywords: Healthy diet; Physical activity; Weight loss

\section{Introduction}

Over the last decades, overweight and obesity have become one of the greatest public health problems worldwide. Previously affecting exclusively developed countries, this problem now affects also developing countries such as Brazil. The projection is that, by 2025, about 2.3 billion adults will be overweightin the world and that more than 700 million people will be obese. This alarming result has been related to high calorie intake, to the reduction of time destined to phyisical exercise, sleep deprivation, and mental factors such as depression and anxiety [1].

To conceptualize overweight and obesity, the World Health Organization (WHO) uses the Body Mass Index (BMI). This classifies as overweight people with a BMI of 25 to $29.9 \mathrm{~kg} / \mathrm{m}^{2}$ and obesity as people with a BMI over $30 \mathrm{~kg} / \mathrm{m}^{2}$. Because it is simple to apply and cost-effective, BMI is still the most widely used method, but it has limitations, such as not differentiating fat from lean mass. Electrical bioimpedance seems to try to minimize this body fat analysis bias because it examines body composition individually: body fat, visceral fat, basal metabolism, skeletal disorders muscles, age and body water $[1,2]$.

Overweight and obese people have a higher risk of morbidity due to hypertension, type 2 diabetes, dyslipidemia, coronary artery disease, heart attack, respiratory diseases, osteomuscular diseases, and neoplasias. In addition, there is also an increase in mortality due to cardiovascular disease among overweight people. In order to reduce the prevalence of excess weight and the complications related to this global epidemic, it is necessary to implement health promotion and preventive measures with the adoption of healthy life habits [1,3-6].

The two main factors for weight loss are undoubtedly a healthy eating associated with exercise. According to the Brazilian Society of Diabetes, 7\% weight loss combined with 150 minutes of moderate physical activity or 75 minutes of vigorous weekly physical activity results in reduced risk of diabetes in prediabetic or overweight patients. According to the Brazilian Society of Cardiology, overweight reduction, regular exercise and healthy eating are essential for the prevention and control of cardiovascular disease. And finally, the 
Citation: Chaves AC, Borges RMC, Lima AC, Paz ÁS, Ono LM, et al. (2019) Good Life Project: Description of the Impact of Weight Loss Intervention at a Private Health Service in Manaus. J Food Sci Nut 5: 046.

National Cancer Institute (INCA) states that overweight is strongly related to the risk of developing 13 different cancers [7-9].

There is an urgent need for interventions on the part of health professionals in order to modify this unfavorable outcome that results in a reduced quality of life and life expectancy and in increased health costs for the treatment of diseases secondary to excess weight. Many studies have reported positive results after interventions involving public policies and the monitoring of people for a given period of time, with the implementation of actions such as weight monitoring and laboratory tests, health promotion campaigns, encouragement of the regular practice of physical exercises, and the adoption of a healthy diet [10-12].

Thus, in view of the above considerations, Sensumed Oncologyhas created the Goord Life project, applied to its staff in order to encourage weight loss by means of lectures with dietary guidelines and with emphasis on the importance of regular physical exercise.

\section{Material and Methods}

A longitudinal, prospective, observational and descriptive study was conducted on 41 employees of Sensumed Oncologia, who represent the entire administrative (23), nursing (4), medical physicist (2), radiotherapy and chemotherapy's technical area (9), and general services staff (3). Exclusion criteria were: employees who a) had been admitted after the beginning of the project, b) had left the clinic during the follow-up period, c) were pregnant or had become pregnant during the course of the project, $d$ ) did not perform the laboratory exams and/or bioimpedance during the months initially planned.

The professionals of Sensumed Oncologia included in the study were first contacted in a doctor's office by the investigators, where they were informed about the methodology and objectives of the investigation and gave written consent to participate in the study.

Body Mass Index (BMI) was calculated and analyzed according to sex using the body weight and height measured during the initial visit and in the 6th month of the study using aWelmy W200/5 scale with a $200 \mathrm{~kg}$ measuring capacity. Bioimpedance was performed in the initial month and in the 6th month of the study using a tetrapolar single frequency Biodynamics analyzer, model 450. Laboratory tests were performed in the initial month and the 6th month by the Santa Clara laboratory (Manaus-AM). During the six months follow-up, Sensumed Oncologia promoted educational lectures about healthy eating habits and provided guidelines about myths and truths and indications and contraindications of regular physical exercise.

Data regarding age, sex, comorbidities, morbid-family history and life habits were collected by brief anamnesis. Body weight and height were measured for the calculation of BMI, serial laboratory exams were obtained and bioimpedance was performed.

Descriptive analysis of the continuous variables is reported as the mean and as absolute and percent frequency. Data were analyzed statistically using the Excel 2010 software.

\section{Results}

Initially, 41 employees satisfied the criteria for inclusion in the project. Of these, 4 did not wish to participate in the Good Life project and one was excluded after becoming pregnant during the study.
Of the 36 employees who started the project, only 29 were submitted to medical examination for the calculation of BMI. However, only 18 subjects fully participated in the first phase of the project and were submitted to bioimpedance, BMI calculation and laboratory tests. These same 18 employees then participated in the second phase of the project with repetition of the exams for comparative analysis (Table 1).

\begin{tabular}{|c|c|c|}
\hline Variables & $\mathbf{N}$ & $\%$ \\
\hline \multicolumn{3}{|l|}{ Gender } \\
\hline Male & 3 & $16.67 \%$ \\
\hline Female & 15 & $83.33 \%$ \\
\hline \multicolumn{3}{|l|}{ Age } \\
\hline $20-30$ years & 8 & $44.44 \%$ \\
\hline $31-40$ years & 3 & $16.67 \%$ \\
\hline $41-50$ years & 6 & $33.33 \%$ \\
\hline$>50$ years & 1 & $5.56 \%$ \\
\hline \multicolumn{3}{|l|}{ Morbid-personal history } \\
\hline Cardiovascular diseases and/or Diabetes Mellitus & 1 & $5.56 \%$ \\
\hline They deny cardiovascular diseases and/or Diabetes Mellitus & 17 & $94.44 \%$ \\
\hline \multicolumn{3}{|l|}{ Morbid-family history } \\
\hline Cardiovascular diseasesand/or Diabetes Mellitus & 13 & $72.22 \%$ \\
\hline They deny cardiovascul diseases and/or Diabetes Mellitus & 5 & $27.78 \%$ \\
\hline \multicolumn{3}{|l|}{ Alcoholism } \\
\hline Yes & 9 & $50.00 \%$ \\
\hline No & 9 & $50.00 \%$ \\
\hline \multicolumn{3}{|l|}{ Smoking } \\
\hline Yes & 1 & $5.56 \%$ \\
\hline No & 17 & $94.44 \%$ \\
\hline \multicolumn{3}{|l|}{ Physical exercise } \\
\hline Yes & $13^{*}$ & $72.22 \%$ \\
\hline No & 5 & $27.78 \%$ \\
\hline
\end{tabular}

Note: *Five of the 13 employees started physical activity after the beginning of the project.

Source: Original elaboration.

\section{Socio-epidemiological data}

The participants responded to an initial questionnaire concerning the following data: gender,age, morbid-personal history, morbid-family history, alcohol consumption, smoking, and physical activity (quantitated as hours/week). The data are presented in table 1.

Among the participants, $83.33 \%$ were females and $16.66 \%$ were males. Only one participant reported a morbid-personal history of cardiovascular disease and/or diabetes, while $72.22 \%$ reported diseases as morbid-family antecedents.

Regarding life habits, $50 \%$ of the subjects reported social alcohol drinking and only one was a smoker. The practice of physical activity at a frequency of 3 times a week or more was reported by $72.22 \%$ of the employees. Of the 13 employees who engaged in physical activity, 5 started to do so after the beginning of the project.

The mean value of the practice of physical activity among the 13 subjects who engaged in physical activity was 3.55 hours/week, with 
Citation: Chaves AC, Borges RMC, Lima AC, Paz ÁS, Ono LM, et al. (2019) Good Life Project: Description of the Impact of Weight Loss Intervention at a Private Health Service in Manaus. J Food Sci Nut 5: 046.

no marked differences between genders, with 3.5 hours/week among women and 3.6 hours/week among men.

\section{Weight loss}

Twenty-nine of the 36 participants attended the weighing sessions on the dayspreviously scheduled (Initial Month and Month 6 of follow-up) and were therefore submitted to BMI calculation for comparative analysis.

Eleven participants coursed with a weight gain ranging from $0.22 \%$ to $5.57 \%$ of body weight, with a total positive gain of $19.3 \mathrm{~kg}$. The remaining 18 employees coursed with a weight loss in the 1.08$14.34 \%$ range, for a total loss of $43.74 \mathrm{~kg}$, as shown in Tables 2 and 3 .

\begin{tabular}{|c|c|c|c|c|}
\hline \multirow{2}{*}{ Initial Weight (kg) } & \multirow{2}{*}{$\begin{array}{c}\text { BMI } 1 \\
\left(\mathrm{~kg} / \mathrm{m}^{2}\right)\end{array}$} & \multirow{2}{*}{ Final Weight (kg) } & \multirow{2}{*}{$\begin{array}{l}\text { BMI } 2 \\
\left(\mathrm{~kg} / \mathrm{m}^{2}\right)\end{array}$} & \multirow{2}{*}{$\%$ Variation } \\
\hline & & & & \\
\hline 86 & 31.5 & 86.6 & 31.8 & $0.70 \%$ \\
\hline 53.9 & 22.7 & 56.2 & 23.7 & $4.27 \%$ \\
\hline 69.15 & 29.1 & 73 & 30.8 & $5.57 \%$ \\
\hline 70 & 26.3 & 68.3 & 25.7 & $-2.43 \%$ \\
\hline 63.5 & 23.6 & 63.5 & 23.6 & $0.00 \%$ \\
\hline 105.8 & 34.9 & 100.8 & 33.3 & $-4.73 \%$ \\
\hline 60 & 24 & 58.8 & 23.6 & $-2.00 \%$ \\
\hline 61.9 & 25.1 & 61.1 & 24.8 & $-1.29 \%$ \\
\hline 62.3 & 25.5 & 63.6 & 25.6 & $2.09 \%$ \\
\hline 71.75 & 25.4 & 72 & 25.5 & $0.35 \%$ \\
\hline 74.2 & 26 & 70.7 & 24.8 & $-4.72 \%$ \\
\hline 58 & 21.3 & 60.1 & 22.1 & $3.62 \%$ \\
\hline 46.8 & 16.8 & 45 & 16.1 & $-3.85 \%$ \\
\hline 52.3 & 23.6 & 50.6 & 22.8 & $-3.25 \%$ \\
\hline 89.8 & 29.3 & 90 & 29.4 & $0.22 \%$ \\
\hline 93.2 & 36.9 & 90.1 & 35.6 & $-3.33 \%$ \\
\hline 68.84 & 25.9 & 67.6 & 25.5 & $-1.80 \%$ \\
\hline 81.6 & 34.4 & 69.9 & 29.5 & $-14.34 \%$ \\
\hline
\end{tabular}

Table 2: Weight loss (Participated in all stages of the project).

Source: Original elaboration.

BMI: Body Mass Index.

\section{Laboratory exams}

The results of the laboratory exams are reported as sample mean and percent variation. After 6 months of health-promoting activities, $61.11 \%$ of the participants showed a reduction of glycemia levels compared to the sample obtained in the first month, and basal insulin was reduced in $55.56 \%$ of the study sample. HDL cholesterol increased in only $16.67 \%$ of cases, but LDL levels decreased in $61.11 \%$ of cases.

It should, also, be pointed out that there was an important change in triglyceride levels, with $94.44 \%$ of the participants showing a reduction of basal rates.

Cholesterol variation: On the occasion of the first blood collection for laboratory exams, the mean total cholesterol value was $178.2 \mathrm{mg} /$ $\mathrm{dL}$ for women and $207.6 \mathrm{mg} / \mathrm{dL}$ for men, LDL cholesterol was $102.2 \mathrm{mg} / \mathrm{dL}$ for women and $140.6 \mathrm{mg} / \mathrm{dL}$ for men, and HDL cholesterol HDL was $55.8 \mathrm{mg} / \mathrm{dL}$ for women and $45.3 \mathrm{mg} / \mathrm{dL}$ for men.

\begin{tabular}{|c|c|c|c|c|}
\hline \multirow{2}{*}{ Initial Weight (kg) } & \multirow{2}{*}{$\begin{array}{c}\text { BMI } 1 \\
\left(\mathrm{~kg} / \mathrm{m}^{2}\right)\end{array}$} & \multirow{2}{*}{ Final Weight (kg) } & \multirow{2}{*}{$\begin{array}{c}\text { BMI } 2 \\
\left(\mathrm{~kg} / \mathrm{m}^{2}\right)\end{array}$} & \multirow{2}{*}{$\%$ Variation } \\
\hline & & & & \\
\hline 72.9 & 26.7 & 71.6 & 26.3 & $-1.78 \%$ \\
\hline 78.9 & 26.4 & 78.1 & 26.1 & $-1.01 \%$ \\
\hline 75.8 & 29.6 & 79.8 & 31.2 & $5.28 \%$ \\
\hline 74.2 & 28.2 & 73.4 & 28 & $-1.08 \%$ \\
\hline 59.6 & 24.4 & 57.8 & 23.8 & $-3.02 \%$ \\
\hline 51.1 & 21.8 & 52.1 & 22.3 & $1.96 \%$ \\
\hline 93.2 & 36.9 & 90.1 & 35.6 & $-3.33 \%$ \\
\hline 68.84 & 25.9 & 67.6 & 25.5 & $-1.80 \%$ \\
\hline 81.6 & 34.4 & 69.9 & 29.5 & $-14.34 \%$ \\
\hline 83 & 33.2 & 83 & 33.2 & $0.00 \%$ \\
\hline 77.9 & 26.3 & 80.3 & 27.1 & $3.08 \%$ \\
\hline 101.5 & 33.3 & 96.4 & 31.8 & $-5.02 \%$ \\
\hline 68 & 23 & 65.8 & 22.8 & $-3.24 \%$ \\
\hline 79.4 & 31 & 80.7 & 31.5 & $1.64 \%$ \\
\hline 89.8 & 29.3 & 90 & 29.4 & $0.22 \%$ \\
\hline 93.2 & 36.9 & 90.1 & 35.6 & $-3.33 \%$ \\
\hline 68.84 & 25.9 & 67.6 & 25.5 & $-1.80 \%$ \\
\hline 81.6 & 34.4 & 69.9 & 29.5 & $-14.34 \%$ \\
\hline
\end{tabular}

Table 3: Weight loss (Only participated in the weighing phase).

Source: Original elaboration.

BMI: Body Mass Index.

In the second sample obtained in the $6^{\text {th }}$ month of follow-up, total cholesterol amd LDL cholesterol levels were reduced in both men and women, but there was also a reduction of HDL cholesterol. The mean total cholesterol value was $129.8 \mathrm{mg} / \mathrm{dL}$ for women and $206.6 \mathrm{mg} / \mathrm{dL}$ for men and the nean LDL cholesterol value was $87.0 \mathrm{mg} / \mathrm{dL}$ for women and $149 \mathrm{mg} / \mathrm{dL}$ for men. However, the mean HDL cholesterol value was reduced to $38.8 \mathrm{mg} / \mathrm{dL}$ for women and $38.3 \mathrm{mg} / \mathrm{dL}$ for men, as shown in figure 1.

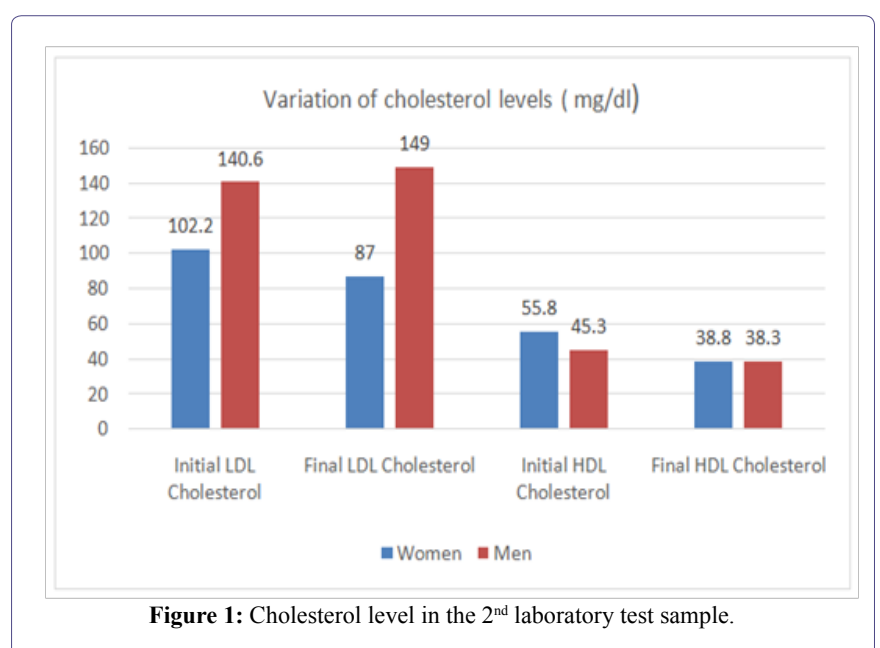

Triglyceride variation: An important reduction in triglyceride rates occurred during the study, especially among women, as shown in figure 2. The mean triglyceride value was reduced from $101.9 \mathrm{mg} / \mathrm{dL}$ in the first sample to $55.26 \mathrm{mg} / \mathrm{dL}$ in the second for women and from $106.6 \mathrm{mg} / \mathrm{dL}$ to $98.6 \mathrm{mg} / \mathrm{dL}$ for men. 


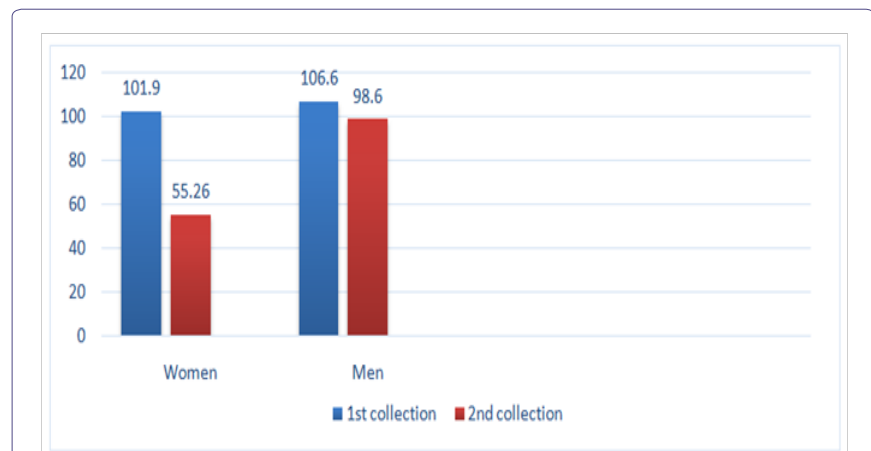

Figure 2: Variation of triglycerides between the 1st and 2nd sample for laboratory tests.

Variation of glycemia and basal insulin: Mean fasting glycemia was $74.6 \mathrm{mg} / \mathrm{dL}$ in the first exam and $72.6 \mathrm{mg} / \mathrm{dL}$ in the second for women, as shown in table 4 , and basal insulin was reduced from $7 \mathrm{mcU} / \mathrm{mL}$ to $5.9 \mathrm{mcU} / \mathrm{mL}$. For men, mean glycemia was $77 \mathrm{mg} / \mathrm{dLin}$ the first exam and was reduced to $70 \mathrm{mg} / \mathrm{dLin}$ the second; Among men, basal insulin increased from $5.7 \mathrm{mcU} / \mathrm{mL}$ to $6.5 \mathrm{mcU} / \mathrm{mL}$, as shown in table 5 .

\begin{tabular}{|c|c|c|}
\hline Variable & Mean for Women & Mean for Men \\
\hline Glycemia initial month & $74.6 \mathrm{mg} / \mathrm{dl}$ & $77 \mathrm{mg} / \mathrm{dl}$ \\
\hline Glycemia month 6 & $72.6 \mathrm{mg} / \mathrm{dl}$ & $70 \mathrm{mg} / \mathrm{dl}$ \\
\hline
\end{tabular}

Table 4: Variation of mean fasting glycemia values.

\begin{tabular}{|c|c|c|}
\hline Variable & Mean for Women & Mean for Men \\
\hline Insulininitial month & $7.0 \mathrm{mcu} / \mathrm{ml}$ & $5.7 \mathrm{mcu} / \mathrm{ml}$ \\
\hline Insulinmonth 6 & $5.9 \mathrm{mcu} / \mathrm{ml}$ & $6.5 \mathrm{mcu} / \mathrm{ml}$ \\
\hline
\end{tabular}

Table 5: Variation of mean basal insulin values.

Bioimpedance: The mean variation of bioimpedance from the first to the sixth month was not so expressive. Lean mass increased from 66.3 to $67.4 \%$ among women and decreased from $75.9 \%$ to $75.8 \%$ among men, as shown in figure 3 .

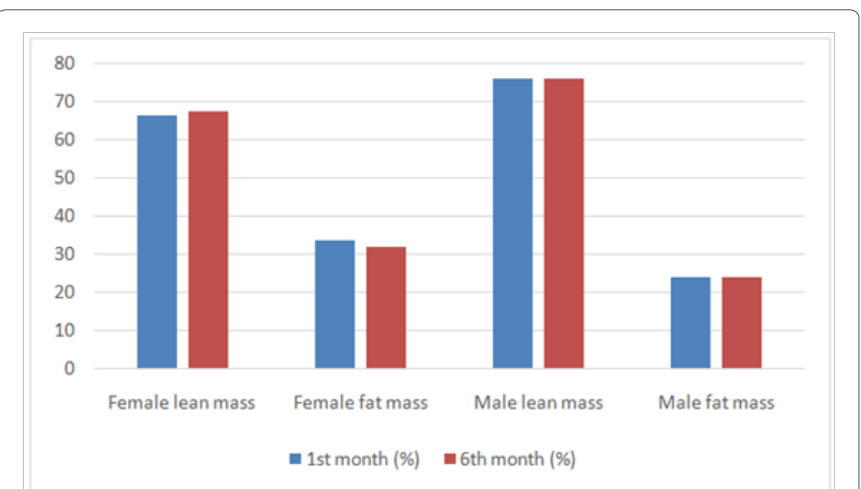

Figure 3: Variation of mean bioimpedance values in the 1st and 6th month (lean mass).

\section{Discussion}

Obesity is a major public health problem, being related to cardiovascular, metabolic, oncologic, mental, psychological and social health. The calamity for the health of both developed and developing countries is that obesity is starting and becoming established at increasingly earlier ages $[1,13,14]$.

The prevalence of overweight $\left(\mathrm{BMI}>25 \mathrm{~kg} / \mathrm{m}^{2}\right)$ and of obesity $\left(\mathrm{BMI}>30 \mathrm{~kg} / \mathrm{m}^{2}\right)$ is progressively increasing, a reality that is also being observed in the city of Manaus. The cause of obesity is known to be multifactorial, although the major features of the disease are due to the increased intake of industrialized food, to a reduction of energy expenditure by the population and to the lack of physical activity in the daily routine [15].

Published investigations have demonstrated that the encouragement of changes in community life style can have positive results, in addition to interventions in health promotion and in the habits of people. The promise study conducted in England has shown important positive weight loss in primary care when coaches and health agents specializing in the promotion of physical activity and in patient follow-up provide support measures [16-18].

Another study measured social support for a healthy diet and the practice of physical activity for 12 months in a weight loss program. The results suggested that solid psychometric measures can be used for knowledge and for personalized clinical interventions with the social support of relatives or of close friends who co-participate in the challenge of weight loss [19].

The Good Life project showed that even though most employees did not have a diagnosis of cardiovascular or metabolic comorbidities, they had a family history of these conditions that placed them at risk depending on the lifestyle they adopted. Another interesting results was the initiation of regular physical activity at a frequency of 3 times a week or more, which caused five of the 18 employees $(27.7 \%)$ to leave behind their sedentary status.

During the six months of the project, dynamic interactive lectures were offered to the participants about health promotion, contemplating the main modifiers of obesity, i.e., a healthy diet and regular physical exercise, as well as reinforcement of good habits for quality of life, with discouragement of practices such as smoking, alcohol drinking and sedentarism.

Another important aspect of weight loss is its impact on the quality of life of people. Several studies have demonstrated that, psychologically, excess weight is directly associatedwith low self-esteem, a negative self-image and social stigmatization and discrimination. Validated questionnaires have demonstrated a significant improvement of subjects participating in weight loss programs after 6 months $[14,18,20]$.

Due to the previously mentioned risks of excess weight, several measures are being applied in order to reduce, prevent or treat obesity, such as non-pharmacological treatment with changes in lifestyle and pharmacological or surgical treatment [21].

Among the main non-pharmacological measures is the introduction of regular physical activity and a healthy diet, even though the adoption of simple tasks such as the reduction of sitting time during the daily routineand an increased frequency of movement can have an impact on the reduction or maintenance (another great challenge) of ideal weight [21]. 
Citation: Chaves AC, Borges RMC, Lima AC, Paz ÁS, Ono LM, et al. (2019) Good Life Project: Description of the Impact of Weight Loss Intervention at a Private Health Service in Manaus. J Food Sci Nut 5: 046.

Analysis of the 29 employees who were weighed both at the beginning and at the end of the project showed a total loss of $43.74 \mathrm{~kg}$. Weight loss is directly related to a better control and, in some cases, to the complete resolution of comorbidities such as sleep apnea, diabetes mellitus and hypertension, as reported in a study on the evolution of quality of life and loss of comorbidities in patients submitted to bariatric surgery [14].

Creating an environment that favors good health practices in the workplace, where most of the population spends most of its functional time of day, can generate positive results regarding quality of life and health. The methods described are of low cost and of easy application when compared to pharmacological treatment and surgical intervention.

Regarding the laboratory exams, we observed that the parameters mostly impacted by weight loss were those related to the lipid profile (total cholesterol, LDL cholesterol and triglycerides), although the basal levels of HDL cholesterol were slightly reduced despite the increase in physical activity among the participants. It is important to point out that no questionnaire about diet control was applied to the participants, so that it was not possible to relate HDL cholesterol levels to the diet adopted.

However, a study with nutritional intervention conducted over a period of 4 months demonstrated a significant reduction of BMI, abdominal circumference, glycemia and triglycerides after changes in eating habits, although without evidence of important improvement of HDL or LDL cholesterol, in agreement with the results of the present study [22].

The bioimpedance exams performed in the initial month and in the 6th month of follow-up in the 18 participants who concluded all the stages of the project showed a discrete increase in lean mass gain among women and a smaller variation in lean mass among men, who had a slightly more modest reduction.

A study reporting intervention with regular physical activity over a period of 4 months showed reduction of systolic pressure, cardiorespiratory conditioning, flexibility and improvement of the metabolic profile and glycemia in a group of hypertensive persons. However, it was observed that during the study period it was not possible to reduce fat percent or BMI in a significant manner, as also observed in the present study [23].

The Good Life project had some limitations. The employees of the company worked in two shifts, a fact that impaired the execution of certain steps of the project by some participants, such as the application of laboratory tests to participants who only worked in the afternoon shift. Another limitation was the lack of detailed control of adhesion to the diet and physical activity during the study period. Also, psychological or emotional aspects were not evaluated. Finally, the observational design of the study did not permit direct interventions in the life habits of the study population.

\section{Authors' Contributions}

Ananda Castro Chaves, Ábner Souza Paz, Ana Cecília de Souza Lima, Rafaela Melo Campos Borges, and Caroline Souza dos Anjos conceived the study and interpreted the data. Caroline Souza dos Anjos and Lia Mizobe Ono performed a critical revision. Caroline Souza dos Anjos and William Hiromi Fuzita approved the final vesion of the paper.

\section{Conflicts of Interest}

None.

\section{Acknowledgment}

We are grateful to Sensumed Oncologia for support with the conception and development of the project.

\section{References}

1. ABESO (2016) Diretrizes Brasileiras de Obesidade. Associação Brasileira para o Estudo da Obesidade e da Síndrome Metabólica, São Paulo, Brazil.

2. Nunes RR, Clemente ELS, Pandini JÁ, Cobas RA, Dias VM, et al. (2009) Confiabilidade da classificação do estado nutricional obtida através do BMI e três diferentes métodos de percentual de gordura corporal em pacientes com diabetes melito tipo 1. Arq Bras Endocrinol Metabol 53: 360 367.

3. Douketis JD, Macie C, Thabane L, Williamson DF (2005) Systematic review of long-term weight loss studies in obese adults: Clinical significance and applicability to clinical practice. Int J Obes (Lond) 29: 1153-1167.

4. Colditz GA, Sellers TA, Trapido E (2006) Epidemiology-identifying the causes and preventability of cancer? Nat Rev Cancer 6: 75-83.

5. Knowler WC, Barrett-Connor E, Fowler SE, Hamman RF, Lachin JM, et al. (2002) Reduction in the incidence of type 2 diabetes with lifestyle intervention or metformin. N Engl J Med 346: 393-403.

6. Prado WL, Siegfried A, Dâmaso AR, Carnier J, Piano A, et al. (2009) Effects of long-term multidisciplinary inpatient therapy on body composition of severely obese adolescents. J Pediatr (Rio J) 85: 243-248.

7. Diretrizes da Sociedade Brasileira de Diabetes 2017-2018/Organização José Egídio Paulo de Oliveira, Renan Magalhães Montenegro Junior, Sérgio Vencio. -- São Paulo: Editora Clannad, 2017.

8. Instituto Nacional do Câncer. Peso Corporal.

9. Simão AF, Precoma DB, Andrade JP, Correa Filho H, Saraiva JFK, et al. (2013) I Diretriz Brasileira de Prevenção Cardiovascular. Sociedade Brasileira de Cardiologia (6, Supl. 2).

10. Franzoni B, Lima LA, Castoldi L, Labrêa MGA (2013) Avaliação da efetividade na mudança de hábitos com intervenção nutricional em grupo. Cien Saude Colet 18: 3751-3758.

11. Machado JC, Cotta RMM, Silva LS (2014) Abordagem do desvio positivo para a mudança de comportamento alimentar: Revisão sistemática. Rev Panam Salud Publica 36: 134-140.

12. Viana LV, Paula TP, Leitão CB, Azevedo MJ (2013) Fatores determinantes de perda de peso em adultos submetidos a intervenções dietoterápicas. Arq Bras Endocrinol Metabol 57: 717-721.

13. McDowell K, Petrie MC, Raihan NA, Logue J (2018) Effects of intentional weight loss in patients with obesity and heart failure: A systematic review. Obes Rev 19: 1189-1204.

14. Castanha CR, Ferraz AAB, Castanha AR, Belo GQMB, Lacerda RMR, et al. (2018) Avaliação da qualidade de vida, perda de peso e comorbidades de pacientes submetidos à cirurgia bariátrica. Rev Col Bras Cir 45: 1864

15. Malta DC, Andrade SC, Claro RM, Bernal RTI, Monteiro CA (2014) Evolução anual da prevalência de excesso de peso e obesidade em adultos nas capitais dos 26 estados brasileiros e no Distrito Federal entre 2006 e 2012. Rev Bras Epidemiol Suppl Pense 17: 267-276.

16. Dutton GR, Lewis CE, Cherrington A, Pisu M, Richman J, et al. (2018) A weight loss intervention delivered by peer coaches in primary care: Rationale and study design of the PROMISE trial. Contemp Clin Trials 72: 53-61. 
Citation: Chaves AC, Borges RMC, Lima AC, Paz ÁS, Ono LM, et al. (2019) Good Life Project: Description of the Impact of Weight Loss Intervention at a Private Health Service in Manaus. J Food Sci Nut 5: 046.

17. Nor NSM, Ambak R, Aris T (2018) An introduction to the my body is fit and fabulous at home (MyBFF@home): A community-based weight loss intervention study among Malaysian housewives. BMC Womens Health 18: 107

18. Perez-Sousa MA, Olivares PR, Escobar-Alvarez JA, Parraça JA, Gusi N (2018) Fitness as mediator between weight status and dimensions of health-related quality of life. Health and Qual Life Outcomes 16: 155

19. Rieger E, Sellbom M, Murray K, Caterson I (2018) Measuring social support for healthy eating and physical activity in obesity. Br J Health Psychol 23: 1021-1039.

20. Ambak R, Nor NSM, Puteh N, Tamil AM, Omar MA, et al. (2018) The effect of weight loss intervention programme on health-related quality of life among low income overweight and obese housewives in the MyBFF@ home study. BMC Women's Health 18: 111.
21. Fanning J, Opina MT, Leng I, Lyles MF, Nicklas BJ, et al. (2018) Empowered with Movement to Prevent Obesity \& Weight Regain (EMPOWER): Design and methods. Contemp Clin Trials 72: 35-42.

22. Busnello FM, Bodanese LC, Pellanda LC, Santos ZEA (2011) Intervenção nutricional e o impacto na adesão ao tratamento em pacientes com síndrome metabólica. Arq Bras Cardiol 97: 217-224.

23. Monteiro HL, Rolim LMC, Squinca DA, Silva FC, Ticianeli CCC, et al. (2007) Efetividade de um programa de exercícios no condicionamento físico, perfil metabólico e pressão arterial de pacientes hipertensos. Rev Bras Med Esporte 13: 107-112. 


\section{dit}

Journal of Anesthesia \& Clinical Care

Journal of Addiction \& Addictive Disorders

Advances in Microbiology Research

Advances in Industrial Biotechnology

Journal of Agronomy \& Agricultural Science

Journal of AIDS Clinical Research \& STDs

Journal of Alcoholism, Drug Abuse \& Substance Dependence

Journal of Allergy Disorders \& Therapy

Journal of Alternative, Complementary \& Integrative Medicine

Journal of Alzheimer's \& Neurodegenerative Diseases

Journal of Angiology \& Vascular Surgery

Journal of Animal Research \& Veterinary Science

Archives of Zoological Studies

Archives of Urology

Journal of Atmospheric \& Earth-Sciences

Journal of Aquaculture \& Fisheries

Journal of Biotech Research \& Biochemistry

Journal of Brain \& Neuroscience Research

Journal of Cancer Biology \& Treatment

Journal of Cardiology: Study \& Research

Journal of Cell Biology \& Cell Metabolism

Journal of Clinical Dermatology \& Therapy

Journal of Clinical Immunology \& Immunotherapy

Journal of Clinical Studies \& Medical Case Reports

Journal of Community Medicine \& Public Health Care

Current Trends: Medical \& Biological Engineering

Journal of Cytology \& Tissue Biology

Journal of Dentistry: Oral Health \& Cosmesis

Journal of Diabetes \& Metabolic Disorders

Journal of Dairy Research \& Technology

Journal of Emergency Medicine Trauma \& Surgical Care

Journal of Environmental Science: Current Research

Journal of Food Science \& Nutrition

Journal of Forensic, Legal \& Investigative Sciences

Journal of Gastroenterology \& Hepatology Research

Journal of Gerontology \& Geriatric Medicine
Journal of Genetics \& Genomic Sciences

Journal of Hematology, Blood Transfusion \& Disorders

Journal of Human Endocrinology

Journal of Hospice \& Palliative Medical Care

Journal of Internal Medicine \& Primary Healthcare

Journal of Infectious \& Non Infectious Diseases

Journal of Light \& Laser: Current Trends

Journal of Modern Chemical Sciences

Journal of Medicine: Study \& Research

Journal of Nanotechnology: Nanomedicine \& Nanobiotechnology

Journal of Neonatology \& Clinical Pediatrics

Journal of Nephrology \& Renal Therapy

Journal of Non Invasive Vascular Investigation

Journal of Nuclear Medicine, Radiology \& Radiation Therapy

Journal of Obesity \& Weight Loss

Journal of Orthopedic Research \& Physiotherapy

Journal of Otolaryngology, Head \& Neck Surgery

Journal of Protein Research \& Bioinformatics

Journal of Pathology Clinical \& Medical Research

Journal of Pharmacology, Pharmaceutics \& Pharmacovigilance

Journal of Physical Medicine, Rehabilitation \& Disabilities

Journal of Plant Science: Current Research

Journal of Psychiatry, Depression \& Anxiety

Journal of Pulmonary Medicine \& Respiratory Research

Journal of Practical \& Professional Nursing

Journal of Reproductive Medicine, Gynaecology \& Obstetrics

Journal of Stem Cells Research, Development \& Therapy

Journal of Surgery: Current Trends \& Innovations

Journal of Toxicology: Current Research

Journal of Translational Science and Research

Trends in Anatomy \& Physiology

Journal of Vaccines Research \& Vaccination

Journal of Virology \& Antivirals

Archives of Surgery and Surgical Education

Sports Medicine and Injury Care Journal

International Journal of Case Reports and Therapeutic Studies

Journal of Ecology Research and Conservation Biology

Submit Your Manuscript: http://www.heraldopenaccess.us/Online-Submission.php 